\title{
Decentralization of health resources to local governments in Burkino Faso
}

Citation for published version (APA):

Zon, H. (2021). Decentralization of health resources to local governments in Burkino Faso. [Doctoral Thesis, Maastricht University]. Gildeprint Drukkerijen. https://doi.org/10.26481/dis.20212206hz

Document status and date:

Published: 01/01/2021

DOI:

10.26481/dis.20212206hz

Document Version:

Publisher's PDF, also known as Version of record

\section{Please check the document version of this publication:}

- A submitted manuscript is the version of the article upon submission and before peer-review. There can be important differences between the submitted version and the official published version of record.

People interested in the research are advised to contact the author for the final version of the publication, or visit the DOI to the publisher's website.

- The final author version and the galley proof are versions of the publication after peer review.

- The final published version features the final layout of the paper including the volume, issue and page numbers.

Link to publication

\footnotetext{
General rights rights.

- You may freely distribute the URL identifying the publication in the public portal. please follow below link for the End User Agreement:

www.umlib.nl/taverne-license

Take down policy

If you believe that this document breaches copyright please contact us at:

repository@maastrichtuniversity.nl

providing details and we will investigate your claim.
}

Copyright and moral rights for the publications made accessible in the public portal are retained by the authors and/or other copyright owners and it is a condition of accessing publications that users recognise and abide by the legal requirements associated with these

- Users may download and print one copy of any publication from the public portal for the purpose of private study or research.

- You may not further distribute the material or use it for any profit-making activity or commercial gain

If the publication is distributed under the terms of Article $25 \mathrm{fa}$ of the Dutch Copyright Act, indicated by the "Taverne" license above, 


\section{SUMMARY \\ IN ENGLISH AND FRENCH}




\section{SUMMARY}

\section{DECENTRALIZATION AND HEALTH RESOURCES TRANSFER TO LOCAL GOVERNMENTS IN BURKINA FASO}

This dissertation examines the decentralization of health resources to local governments in Burkina Faso.

The aim was to explore the process and mechanisms of the transfer of health resources from the central government to the local governments in Burkina Faso. The dissertation also sought to analyze the differences in the distribution of health resources and the differences in health outcomes, and to assess the determinants of access to healthcare during the period of healthcare decentralization in Burkina Faso.

The general introduction of the dissertation presented in Chapter 1, provides an overview of the concept of decentralization and its rationale.

Decentralization refers to the restructuring or reorganization of authority so that there is a system of co-responsibility between institutions of governance at the central, regional and local levels according to the principle of subsidiarity. Decentralization may also be defined as any act through which a central government formally cedes powers to actors and institutions at lower levels in a political-administrative and territorial hierarchy. Over the past decades, many Sub-Saharan African countries have undergone decentralization reforms with the overall goal of improving efficiency, access and equity in the delivery of public services provided through or facilitated by local government authorities. These decentralization policy reforms were largely supported by international institutions such as the World Bank. Like other Sub-Saharan African countries, since 2009, Burkina Faso has engaged in a process to transfer health resources to local levels in accordance with the decentralization policy. This dissertation specifically explores the process, mechanisms and impacts of the transfer of health resources.

To outline the available empirical evidence and provide a basis for the subsequent empirical investigation, Chapter 2 systematically reviews previous studies on local governments' experience with the provision of health services during and after decentralization reforms in Sub-Saharan African countries. The review was carried out in 2016 and included English and French-language publications that report on empirical studies that addressed the issue of decentralization in relation to health services provision by local governments in Sub-Saharan African countries. In total, 21 publications that met the relevance criteria, were included in the literature review. The analysis of the content of the publications and reports was related to the type 
of publication and study design, key findings regarding the decentralization content, process and effects, as well as conclusions and recommendations.

The review results show that decentralization in general, and resources transfer from the central to local governments in particular, are a highly political issue that influences the healthcare reform strategy on decentralization. As such, most countries in SubSaharan Africa have focused on the decentralization process by enacting numerous policies, regulations and standards with mixed outcomes for health services delivery.

The literature highlights the complexity of implementing decentralization schemes, which strongly impact the health service organization and delivery. The theory of decision space applied in the review indicated that some functions, particularly financing, remain under the control of the central state. A major finding from the literature review is that the effects of decentralization in the field of healthcare are mixed with no clear evidence of a positive impact of decentralization on health services. The expected outcomes in the field of health services delivery in terms of access to services, equity and quality of care are inconclusive. The review has identified some good practices in decentralization and resources transfer, key determinants being the type of decentralization and the government's will to make legislative as well as administrative changes required for effective decentralization.

In Chapter 3, the key decision-makers' knowledge, attitudes and practices (KAP) related to decentralization and health resources transfer in Burkina Faso are investigated. Data were collected through a qualitative study using in-depth semi-structured interviews with decision-makers, namely the mayors of municipalities, health district managers and managers of healthcare center as well as policy decision-makers at a regional and national level, and donors/partners. A non-probabilistic sampling method was applied and the participants were selected purposely. We use the KAP framework to explore the three dimensions: Knowledge, Attitudes and Practices.

The findings show that all decision-makers who participated in the study, are knowledgeable about the objective and the rationale of decentralization and transfer of health resources to local governments in Burkina Faso. An important finding of this study is the positive opinion expressed by the vast majority of the decision-makers, which likely reflects on their support of the decentralization and health resources transfer policy. The main elements that appear to be motivating their attitude are the expected outcomes from decentralization, notably: i) better management of healthcare facilities; ii) improved capacities of local governments to provide services of better quality to communities, iii) better management of resources transferred, iv) increased population's access to health services, and v) increased local governments' accountability towards communities and beneficiaries. 
While the findings in Chapter 2 suggest that the expected outcomes of decentralization have not yet been demonstrated, the decision-makers' positive attitudes found in this study mainly rely on the theoretical objectives and expected outcomes of decentralization rather than on evidence or concrete achievements. Most of the decision-makers surveyed have not directly participated in the resources transfer process, either because they were not employed in their current position at that time or they were not entitled to participate in that policy phase. The findings highlight, however, that this has not influenced their positive opinion and attitude towards decentralization and resources transfer.

Some major issues were identified by the study as factors that constraint the health resources transfer process to local governments. These include the poor collaboration among health districts and local governments, the delay in the resources transfer due to the central state control over the resources, the complexity of implementing decentralization schemes, which strongly impact: i) the health service organization and delivery, ii) the relationships and responsibilities between local governments and health boards, iii) the coordination and monitoring mechanisms among the stakeholders, and iv) decentralization agencies.

The methodology applied in Chapter 3 was extended to Chapter 4 where the strengths, weaknesses, opportunities, and threats (SWOT) associated with the decentralization and health resources transfer in Burkina Faso were explored from the perspective of decision-makers. We used a qualitative research approach to conducted semistructured interviews with the same key decision-making groups as indicated in chapter 3. The SWOT framework was used for the directed content analysis.

The most cited strengths in this study are political will and improvement of local governance, which also create the opportunity for an enhanced partnership and decentralized cooperation. As expected, however, the limited financial and human resources capacities of local governments are important weaknesses. Furthermore, misuse of financial resources and political interference threatens the resources transfer.

The disaggregation of the responses according to the participants' professional affiliation (health sector and decentralization sector) indicates that the responses seem to be converging to a certain extent. Further analysis done on the basis of mayors' political affiliation (governing and opposition), which is publicly known in contrast with other decision-makers in the study, shows some differences, thereby confirming the highly political nature of decentralization and resources transfer. Decision-makers in this study suggest ways to address the weaknesses and threats related to health resources transfer, which include the enforcement of decentralization's policies and laws, the strengthening of local government capacities, as well as their adequate funding and the regular review of the process of resources transfer. 
In Chapter 5, the differences in health outcomes by health district's demographic and economic status were analyzed, and the distribution of health resources during the period of healthcare decentralization in Burkina Faso was studied. A quantitative analytical method was applied to explore associations between districts' demographics and economic profile, health resources, health outcomes, and health status. For this purpose, a database was created using district and region level data sourced from the health management information systems (HMIS) and national households' surveys. The data collection points for all sources were 2010 and 2014.

The findings indicate a strong correlation between the district's population size and the availability of health resources $(p<.05)$. Health outcomes such as healthcare visits per capita and skilled birth attendance are correlated with the economic status of the health district. Also, malnutrition among children under-five and maternal mortality were associated with the availability of healthcare personnel and health infrastructure $(p<.05)$. The data collected show that poverty has dropped considerably between 2010 and 2014, and it has even halved in some districts. This suggests a great achievement in poverty reduction, one of the stated aims of decentralization. However, this progress has not resulted in a reduction of inequality in income between the different regions and a more equitable distribution of resources across health districts. The inequality between urban and rural regions has even deepened, as well as between the welloff and poorest regions. The inequality in households' income was exacerbated predominantly in better-off regions, doubling or tripling in some of these regions. The root causes of these disparities across health districts and regions are to be found in the resource allocation approaches and mechanisms, as well as the policies to address the socio-economic inequalities and financial barriers to health services.

In Chapter 6, a quantitative research method was applied to analyze the factors associated with households' access to healthcare in Burkina Faso. The data were sourced from a national household survey conducted in 2014

The findings show that the main source of health-seeking by the majority of patients $(81.39 \%)$ are the primary healthcare facilities placed under the responsibility of local governments within the health resources transfer policy. Further analysis found that young children that represent $31.20 \%$ of the patients are the largest healthcare consumers. The average direct costs of health services incurred by households during the last episode of seeking care, is estimated to be $\$ 28$, in a context where the social welfare system is very limited, thereby exposing households to catastrophic expenditures. The out-of-pocket expenditures were estimated to constitute $31.7 \%$ of total healthcare spending (WHO, 2017). It emerges from the analysis in this chapter that the key factors that affect the households' healthcare expenditure are age, type of healthcare facility used, distance traveled and place of residence. Thus, households 
spend more on health services for children under 5 compared to other age groups. This suggests that the number of young children is a stronger determinant of households' out-of-pocket payments because of the early-age illnesses. Seeking care in district hospitals and primary healthcare facilities, which accounts for $81.39 \%$ of healthseeking sources, increases healthcare expenditure for households. Households' healthcare expenditures are heightened by indirect costs such as travel costs due to the distance to healthcare facilities and the area of residence. Distance to healthcare facilities leads to high treatment costs for households. The findings also suggest that patients' place of residence impacts costs. Overall, the objective of the health system to ensure equal access to healthcare for all and to guarantee financial risk protection towards universal coverage, has not yet materialized.

Finally, in Chapter 7 the main findings are summarized and discussed from the perspective of policy development and policy implications. We draw conclusions on how to strengthen decentralization and improve health resources transfer to local level.

The chapter indicates that the decentralization policy and reforms implemented in Sub-Saharan African countries are primarily intended to improve the delivery of public services, including health services. This involves the effective transfer of functions, power and authorities to local entities. Based on the results of the research in SubSaharan Africa, the chapter discusses the effects of decentralization on health services delivery. The overall conclusion is that decentralization often fails to achieve its end in Sub-Saharan Africa, despite progress in individual countries. Most of the countries have mainly focused on the process by enacting numerous policies, regulations and standards that result in mitigated outcomes in health services delivery. The expected outcomes in terms of the provision of equitable, effective and quality healthcare are inconclusive. It is important to recognize that decentralization is a political decision and its implementation is a reflection of a country's political process and institutional design.

This final chapter also emphasizes the policy implications for Burkina Faso and other Sub-Saharan African countries for the provision of equitable, efficient and quality healthcare for achieving the goal of universal health coverage. Hence, countries need to assess their decentralization and health resources transfer policies with particular attention to the definition of decentralization objectives and expected outcomes, the political dimensions and country institutional context, the stakeholders' awareness and understanding, as well their roles and responsibilities, local governments capacities, funding of the decentralization policy implementation, policies that address health inequalities and barriers in healthcare access, monitoring-evaluation and accountability mechanisms. 


\section{RESUME}

\section{DÉCENTRALISATION ET TRANSFERT DES RESSOURCES EN SANTÉ AUX COMMUNES AU BURKINA FASO}

La présente dissertation porte sur le transfert des ressources dans le domaine de la santé aux communes au Burkina Faso. L'objectif est d'explorer le processus, les mécanismes du transfert des ressources en santé de l'Etat aux communes; d'analyser les différences dans la distribution des ressources en santé et l'état de santé des populations ; d'analyser les déterminants de l'accès aux services de santé pendant la période de la décentralisation au Burkina Faso en vue de contribuer à une meilleure compréhension des questions et défis inhérents au processus de transfert des ressources en santé.

Le Chapitre 1 de la thèse présente l'introduction générale, un aperçu du concept et de la justification de la politique de décentralisation.

Le concept de décentralisation renvoie à la restructuration ou la réorganisation de l'autorité pour instaurer un système de coresponsabilité entre les institutions de gouvernance du niveau central, régional et local selon le principe de subsidiarité. La décentralisation peut être également définie comme tout acte par lequel l'Etat central cède formellement des pouvoirs aux acteurs et institutions du niveau local suivant l'organisation politico-administrative et territoriale du pays. Au cours de ces dernières décennies, plusieurs pays d'Afrique subsaharienne ont mené des réformes dans le domaine de la décentralisation avec pour objectif général d'améliorer l'efficience, l'accès et l'équité dans l'offre des services publics par les autorités communales. Ces réformes dans le domaine de la décentralisation étaient largement soutenues par les institutions internationales telle que la Banque Mondiale. A l'instar des pays d'Afrique subsaharienne, le Burkina s'est engagé depuis 2009 dans un processus de transfert des ressources en santé aux communes dans le cadre de la politique globale de la décentralisation. Plus spécifiquement, cette dissertation se propose d'explorer le processus, les mécanismes et effets de cette politique de transfert des ressources en santé aux communes.

Pour documenter les évidences empiriques disponibles et fournir une base pour les études ultérieures, le Chapitre 2 examine à travers une revue systématique de la littérature, des études antérieures sur les expériences des communes en matière d'offres des services de santé, pendant et après la période des réformes des politiques de décentralisation en Afrique Subsaharienne. Cette revue a été réalisée en 2016 et a inclus des publications en langue française et anglaise ayant étudié la question de la décentralisation et de l'offre des services de santé par les communes en Afrique 
Subsaharienne. Au total, 21 publications et rapports répondant aux critères de sélection ont été incluses dans la revue de littérature. L'analyse de contenu des publications et rapports a porté sur : i) le type de publication ou de rapport, ii) la méthodologie de l'étude, iii) les principaux résultats en lien avec le contenu, le processus et les effets de la décentralisation, ainsi que iv) les conclusions et les recommandations.

Les principaux résultats de la revue de la littérature indiquent que la décentralisation en général, et le transfert des ressources de l'Etat central aux communes en particulier revêtent un caractère hautement politique qui influence les stratégies de réformes de la santé en lien avec la décentralisation. Ainsi, la plupart des pays d'Afrique subsaharienne se sont focalisés sur le processus de décentralisation en adoptant de nombreuses politiques, régulations et standards avec des résultats mitigés en matière d'offres de services de santé.

La revue relève par ailleurs la complexité du cadre de mise en œuvre de la décentralisation, ce qui impacte fortement l'organisation et l'offre des services de santé. L'application de la théorie de l'espace de décision ou du pouvoir de décision lors de la revue révèle que certaines fonctions ou domaines, en particulier les finances, demeure sous le contrôle de l'Etat central. Un des constats majeurs de cette revue est que les effets de la décentralisation dans le domaine de la santé sont mitigés, sans une claire évidence de l'impact positif de la décentralisation sur les services de santé. Les résultats attendus dans le domaine de l'offre des services de santé en termes d'accès, d'équité et de qualité des services sont peu concluants.

La revue a toutefois identifié des bonnes pratiques en matière de décentralisation et de transfert des ressources dans certains pays. Les facteurs déterminants sont le type de décentralisation, la volonté de l'Etat central d'opérer les changements législatifs et administratifs nécessaires pour une décentralisation effective.

Dans le Chapitre 3, nous investiguons les connaissances, attitudes et pratiques (CAP) des décideurs clés en lien avec la décentralisation et le transfert des ressources. Les données ont été collectées à travers une étude qualitative. Un interview semistructuré a été réalisé avec les décideurs, notamment : les maires de commune, les responsables de district sanitaire, les responsables de centre de santé, les décideurs politiques au niveau régional et central, ainsi que les partenaires du Burkina dans le domaine de la décentralisation. Un échantillonnage non probabiliste a été réalisé et les participants ont été sélectionnés de manière raisonnée.

Les résultats montrent que toutes les personnes interviewées connaissent les objectifs et la justification de la décentralisation et du transfert des ressources en santé aux communes au Burkina Faso. La grande majorité des décideurs rencontrés ont exprimé 
une opinion positive, ce qui traduirait leur soutien à la politique de décentralisation et de transfert des ressources. Les principaux éléments qui semblent motiver leur attitudes positives sont les résultats attendus de la décentralisation, notamment : i) une meilleure gestion des centres de santé, ii) une amélioration des capacités des communes à fournir des services de qualité aux communautés, iii) une gestion efficiente des ressources transférées, iv) un meilleur accès des populations aux services de santé, et v) un renforcement de la responsabilité et de la redevabilité des communes envers les communautés et les bénéficiaires.

La plupart des décideurs enquêtés n'ont pas directement été impliqués dans le processus de transfert des ressources, soit parce qu'ils n'étaient pas employés dans leur poste actuel ou soit ils n'étaient pas habilités à participer directement au processus. Cependant les résultats montrent que cela n'a pas influencé ou affecté leurs opinions ou attitudes positives envers la décentralisation et le transfert des ressources.

Les résultats de la revue de la littérature présentés dans le Chapitre 2 suggèrent que les effets attendus de la décentralisation en matière d'offres de services de santé n'ont pas été concluants. Cependant, les décideurs interviewés dans cette étude expriment une opinion positive en soutien à la politique de décentralisation au Burkina Faso. Cette attitude positive des décideurs serait fondée principalement sur les objectifs et résultats théoriques de la décentralisation, plutôt que sur des évidences ou des réalisations concrètes

L'étude a révélé des facteurs majeurs qui contraignent le processus de transfert des ressources en santé aux communes. Il s'agit de la faible collaboration entre les équipes de district et des communes, le retard dans le transfert des ressources, la complexité du schéma de mise en œuvre de la décentralisation qui influence grandement : i) l'organisation et l'offre des services de santé, ii) les relations et les responsabilités entre les autorités communales et sanitaires, iii) les mécanismes de coordination et de suivi entre les différentes parties prenantes, et iv) les organes de la décentralisation.

Le Chapitre 4 explore les Forces, Faiblesses, Opportunités et Menaces (FFOM) de la décentralisation et du transfert des ressources en santé aux communes au Burkina Faso. Pour cette étude, nous avons utilisé une méthode d'étude qualitative identique à celle du Chapitre 3, notamment un entretien semi-structuré avec les différents groupes de décideurs dont les profils sont présentés dans le Chapitre 3. La matrice FFOM a été utilisée pour l'analyse de contenu.

Les forces les plus citées par les participants sont la volonté politique et l'amélioration de la gouvernance locale, qui par la même occasion crée une opportunité pour un partenariat renforcé et une coopération décentralisée. Les faiblesses identifiées par 
les enquêtés sont les capacités limitées en ressources financières et humaines des communes qui constituent des goulots d'étranglement majeurs dans le processus de transfert des ressources. En outre, la mauvaise gestion des ressources financières et l'interférence politique menacent le transfert des ressources.

La désagrégation des réponses selon l'affiliation professionnelle des enquêtés (secteur de la santé et secteur de la décentralisation) indique que les réponses semblent convergentes. Une analyse plus approfondie a été réalisée sur la base de l'affiliation politique des maires des communes (parti au pouvoir et opposition), laquelle affiliation est publiquement connue contrairement aux autres groupes de décideurs enquêtés. Les résultats de cette analyse montrent quelques différences, confirmant ainsi le caractère politique de la décentralisation et du transfert des ressources.

Les participants à l'étude ont formulé des suggestions pour la mitigation des faiblesses et des menaces, notamment l'application effective des lois et politiques de la décentralisation, le renforcement des capacités des communes, y compris leur financement adéquat et une revue régulière du processus de transfert des ressources.

Dans le Chapitre 5, une analyse des différences dans la couverture des interventions de santé, du statut de santé des populations selon le profil démographique et économique des districts sanitaires est réalisée. La distribution des ressources en santé pendant la période de décentralisation du système de santé au Burkina Faso est également étudiée. Une méthode d'analyse quantitative a été appliquée pour explorer l'association entre le profil démographique et économique des districts, les ressources en santé, la couverture des interventions et l'état de santé des populations. Pour ce faire, une base de données a été créée en utilisant les données des districts et régions sanitaires provenant du système national d'information sanitaire (SNIS) y compris les données des enquêtes ménages. La collecte des données pour les deux sources (SNIS et enquêtes Ménage) a porté sur l'année 2010 et 2014 en vue d'apprécier les différents changements intervenus au cours de la période du transfert des ressources en santé qui a débuté au Burkina Faso en 2009.

Les résultats indiquent une forte corrélation entre la taille de la population des districts et la disponibilité des ressources en santé $(p<.05)$. La couverture des interventions de santé telles que le nombre de visites/an/habitant et les accouchements assistés sont corrélés avec le statut économique des districts sanitaires. De même, la malnutrition chez les enfants de moins de 5 ans et la mortalité maternelle sont associées à la disponibilité du personnel et des infrastructures de santé $(p<.05)$. Les données collectées montrent que la pauvreté a considérablement diminuée entre 2010 et 2014, et aurait même baissé de moitié dans certains districts sanitaires. Ceci témoigne des progrès considérables réalisés dans la lutte contre la pauvreté qui est l'un des 
objectifs assignés à la décentralisation. Cependant, ces progrès n'ont pas contribué à réduire les inégalités des revenus entre les différentes régions et à assurer une distribution équitable des ressources entre les districts sanitaires. Entre 2010 et 2014, les inégalités entre les régions rurales et urbaines se sont accentuées, aussi bien entre les régions pauvres et les régions riches. Les inégalités de revenus des ménages se sont exacerbées particulièrement dans les régions riches, doublant ou triplant dans certaines régions. Les causes profondes de ces disparités entre les régions et districts sanitaires se trouvent dans les méthodes et mécanismes d'allocation des ressources, aussi bien que dans les politiques de réduction des inégalités socio-économiques et des obstacles financiers dans l'accès aux services de santé.

Dans le Chapitre 6, une méthode quantitative de recherche est appliquée pour étudier les déterminants de l'accès des ménages aux services de santé au Burkina Faso. Les données utilisées proviennent de l'enquête nationale sur les conditions de vie des ménages réalisée en 2014.

Les résultats indiquent que les principales sources pour le recours aux soins pour la majorité des patients $(81,39 \%)$ sont les centres de santé et de promotion sociale (CSPS) qui sont désormais placés sous la responsabilité des communes dans le cadre de la politique de transfert des ressources. L'analyse des données révèle que les enfants qui constituent $31,20 \%$ des patients sont les plus grands consommateurs des soins de santé. Le coût direct moyen des soins payé par les ménages lors du dernier recours aux soins est estimé à \$28 (environ 14000 FCFA) dans un contexte où le système de protection sociale est limité, exposant ainsi les familles à de potentielles dépenses catastrophiques de santé. Selon l'OMS (2017), les dépenses directes de santé supportées par les ménages constituent $31,7 \%$ de leurs dépenses totales de santé. II ressort de l'analyse dans ce chapitre que les principaux facteurs qui influencent les dépenses de santé des ménages sont l'âge, le type de formation sanitaire utilisée, la distance et le lieu de résidence. Ainsi, les ménages dépensent plus pour la santé des enfants de moins de 5 ans que pour les autres groupes d'âge. Ce qui indique que le nombre de jeunes enfants est un facteur prépondérant des dépenses directes de santé des ménages en raison des maladies infantiles plus fréquentes. Le recours aux soins dans les hôpitaux de districts et les CSPS (81,39\% des sources de recours aux soins) augmentent les dépenses de santé des ménages qui par ailleurs sont accentuées par les coûts indirects liés au transport et le milieu de résidence.

D'une manière générale, l'objectif du système de santé d'assurer un accès égal aux soins pour tous et de garantir une protection contre les risques financiers vers la couverture sanitaire universelle, n'est pas encore atteint au Burkina Faso. 
Finalement dans le Chapitre 7, les principaux résultats sont résumés et discutés dans la perspective de l'élaboration et de l'implication des politiques et réformes de la décentralisation. Nous formulons les conclusions pour le renforcement de la décentralisation et l'amélioration du transfert des ressources au niveau local.

Ce chapitre rappelle que les politiques et les réformes de décentralisation mises en œuvre dans les pays d'Afrique subsaharienne avaient pour objectif principal d'améliorer l'offre des services publics, y compris les services de santé. Ce qui implique un transfert effectif des fonctions, des pouvoirs et autorités au niveau local. Sur la base des résultats de notre recherche en Afrique Subsaharienne, les effets de la décentralisation sur l'offre des services de santé sont discutés dans ce chapitre. Il en ressort que la décentralisation ne parvient pas à atteindre sa finalité, malgré les progrès enregistrés dans chaque pays. Dans la plupart des pays, les efforts se sont focalisés essentiellement sur le processus législatif et réglementaire. Les résultats attendus en termes d'offres de services de santé équitables, efficientes et de qualité sont mitigés. Il est important de reconnaitre que la décentralisation est une décision politique et sa mise en œuvre est à l'image du processus politique et de l'organisation institutionnelle du pays.

Dans ce chapitre final, nous soulignons également les implications de la politique de décentralisation au Burkina Faso et dans les autres pays de l'Afrique Subsaharienne, notamment la question de l'offre de services de santé équitables, efficients et de qualité dans la perspective de la couverture sanitaire universelle.

Par conséquent, les pays doivent réévaluer leurs politiques de décentralisation et de transfert des ressources en santé, en portant une attention particulière aux aspects clés ci-après : i) la définition des objectifs et résultats attendus de la décentralisation, ii) les dimensions politiques et l'organisation institutionnelle du pays, iii) l'information et la sensibilisation des différentes parties prenantes ainsi que leurs rôles et responsabilités, iv) les capacités des communes, v) le financement de la politique de décentralisation, vi) les politiques de réduction des inégalités en santé et des obstacles dans l'accès aux soins, vii) les mécanismes de suivi-évaluation et de redevabilité. 